\title{
EFFECT OF $3^{\prime}$-AMINO-2', $3^{\prime}$-DIDEOXYCYTIDINE ON DNA REPLICATIVE INTERMEDIATES
}

\author{
Mark S. Williams* and William R. MaNCini ${ }^{\dagger}$ \\ Department of Pharmacology, University of Michigan Medical School, Ann Arbor, MI 48109-0626, \\ U.S.A.
}

(Received 9 August 1993; accepted 15 December 1993)

\begin{abstract}
Amino-2', 3'-dideoxycytidine $\left(3^{\prime}-\mathrm{NH}_{2}\right.$-ddCyd) is a $3^{\prime}$-modified deoxycytidine analog that specifically inhibits DNA synthesis. Inhibition of chain elongation at the replication fork was examined utilizing a batch hydroxylapatite chromatography method. Exponentially growing cells were exposed to $3^{\prime}-\mathrm{NH}_{2}$-ddCyd and the diterpene aphidicolin for $9.5 \mathrm{hr}$ at concentrations that inhibited DNA synthesis by approximately 60 and $90 \%$, as determined by precursor uptake. Both agents demonstrated a concentration-dependent inhibition of pulse labeling of single-stranded DNA (ssDNA) and doublestranded DNA (dsDNA) generated by a limited alkaline lysis procedure. Upon removal of drug, the rate of elongation of pulse-labeled DNA was similar to that of untreated cells at both concentrations of aphidicolin and at the low concentration of the amino analog. Under these conditions, no reduction in cell survival was observed using the clonogenic assay technique. However, at the high concentration of $3^{\prime}-\mathrm{NH}_{2}$-ddCyd, the rate of elongation following drug removal was one-third that of untreated cultures, and a $50 \%$ loss in cell viability was observed. Furthermore, upon incubation of purified dsDNA with the Klenow fragment of Escherichia coli DNA polymerase I or purified ssDNA with calf thymus terminal deoxynucleotidyl transferase, only DNA from cells treated with the high concentration of $3^{\prime}-\mathrm{NH}_{2}$ ddCyd served as a poor template for further synthesis. The results indicate that $3^{\prime}-\mathrm{NH}_{2}$-ddCyd, in a concentration-dependent manner, inhibits DNA synthesis by reducing the rate of chain elongation at the replication fork, which subsequently leads to a functional blocking of 3 '-ends in DNA. The data suggest that there may be a relationship between loss of cell viability and reduction in the number of $3^{\prime}$-ends available for DNA replication.
\end{abstract}

Key words: DNA replication; didcoxynucleoside; aminonuclcoside; deoxycytidine; antincoplastic agents

The clinical effectiveness of ara-C $¥$ has prompted chemists to modify the dCyd structure with the aim of synthesizing a cytotoxic analog with improved metabolic stability over ara-C, which is known to have a short biological half-life due to enzymatic deamination $[1,2]$. The substitution of an amino group for the hydroxyl normally present at the $3^{\prime}$ position of dCyd yielded a cytotoxic agent, $3^{\prime}-\mathrm{NH}_{2}$ ddCyd, that selectively inhibits DNA synthesis, and is active against murine leukemia in vitro and in vivo [3]. With the use of both purified enzyme [4] and intact cells [5], $3^{T}-\mathrm{NH}_{2}$-ddCyd was found to be highly resistant to deamination, while ara-C was degraded in cells that expressed deaminase activity [5]. Although it is clear that $3^{\prime}-\mathrm{NH}_{2}$-ddCyd is

* Current address: Experimental Immunology Branch, Bldg. 10, Rm. 4B17, National Institutes of Health, Bethesda, MD 20892.

$\dagger$ Corresponding author: Dr. William R. Mancini, Upjohn Center for Clinical Pharmacology, 1310 East Catherine St., Rm. 4302, Ann Arbor, MI 48109-0504. 'Tel. (313) 764-1290; FAX (313) 763-3438.

‡ Abbreviations: ara-C, $1-\beta$-D-arabinofuranosylcytosine; $3^{\prime}-\mathrm{NH}_{2}$-ddCyd, $3^{\prime}$-amino-2', $3^{\prime}$-dideoxycytidine; dNTP, deoxynucleoside-5'-triphosphate; $\quad 3-\mathrm{NH}_{2}$-ddThd, 3 amino- $3^{\prime}$-dideoxythymidine; dThd, deoxythymidine; dCyd, deoxycytidine; AZT, $3^{\prime}$-azido-3'-dideoxythymidine; ddATP, 2', $3^{\prime}$-dideoxyadenosine $5^{\prime}$-triphosphate; ddCyd, 2',3'-dideoxycytidine; ssDNA, single-stranded DNA; dsDNA, double-stranded DNA; TCA, trichloroacetic acid; and HAP, hydroxylapatite. metabolically more stable than ara-C, the mechanism by which the former agent induces a loss of cell viability is not known. Studies with ara-C have shown a correlation between the amount of analog residues incorporated into DNA and the level of cell lethality [6]. Initial attempts to determine whether $3^{\prime}-\mathrm{NH}_{2}$-ddCyd is incorporated into DNA did not detect any $3^{\prime}-\mathrm{NH}_{2}$-ddCMP following HPLC analysis of DNA digests [7]. These experiments were hindered, however, by the lack of a labeled analog of high specific activity and a limited duration of exposure. With these caveats, the data suggested that, under the conditions examined, either a low level of $3^{\prime}-\mathrm{NH}_{2}$-ddCyd incorporation occurred, which could not be resolved by the experimental approach, or that DNA incorporation was not occurring under conditions where DNA synthesis was strongly inhibited.

These observations are consistent with the proposed mechanism of $3^{\prime}-\mathrm{NH}_{2}$-ddThd, which is inhibition of DNA polymerase, since no incorporation of this analog into DNA of cultured tumor cells has been observed [8]. However, the studies utilizing either $3^{\prime}-\mathrm{NH}_{2}$ nucleoside in intact cells $[7,8]$ are not consistent with in vitro experiments.

The $K_{i}$ of $3^{\prime}-\mathrm{NH}_{2}$-ddCTP for DNA polymerase $\alpha$ is $9.6 \mu \mathrm{M}$ [7], which is about 5-fold higher than the $K_{m}$ of dCTP. This ratio predicts that $3^{\prime}-\mathrm{NH}_{2}$-ddCTP is a weak inhibitor of DNA polymerase $\alpha[9]$, and that a mechanism(s) other than competitive inhibition 
of DNA polymerase accounts for the potent inhibition of DNA synthesis. Furthermore, utilizing Escherichia coli polymerase I and mammalian DNA polymerases $\alpha$ and $\beta$ with plasmid pBRS2950 template/primer complex, it was shown that the $3^{\prime}$-amino- $2^{\prime}, 3^{\prime}$-dideoxy-5' -triphosphate analogs of adenosine, guanosine, cytidine, and thymidine were incorporated into the DNA and were effective terminators of DNA synthesis [10]. This was clearly demonstrated for $E$. coli polymerase I and polymerase $\beta$, but the authors did observe unexplainable duplex bands when polymerase $\alpha$ was used, a finding not observed with the other polymerases [10]. It is not known if this represents a unique interaction with the replicative polymerase. Although the concentration of $3^{\prime}-\mathrm{NH}_{2}$-ddCTP used (1 mM) in this in vitro experiment greatly exceeds that which is necessary to inhibit growth of tumor cells in culture $(1 \mu \mathrm{M})$, the same mechanism may be responsible for the cytotoxic effect.

To test whether the hypothesis that $3^{\prime}-\mathrm{NH}_{2}$-ddCTP acts solely through inhibition of DNA polymerase is valid, the present study compared the effects of $3^{\prime}-\mathrm{NH}_{2}$-ddCyd at the replication fork with those of aphidicolin, a competitive inhibitor of the replicating polymerases $\alpha$ and $\delta$, which is not incorporated into DNA $[11,12]$.

\section{MATERIALS AND METHODS}

Materials. $3^{\prime}-\mathrm{NH}_{2}$-ddCyd, the synthesis of which has been reported [3], was provided by Dr. T. S. Lin of Yale University. [ Methyl $-{ }^{3} \mathrm{H}$ ] thymidine $(65 \mathrm{Ci}$ ) $\mathrm{mmol})$ and $\left[2-{ }^{14} \mathrm{C}\right]$ thymidine $(56 \mathrm{Ci} / \mathrm{mmol})$ were purchased from Moravek Biochemicals (La Brea, CA). [Methyl $\left.{ }^{3} \mathrm{H}\right]$ thymidine triphosphate $(84.2 \mathrm{Ci} /$ $\mathrm{mmol})$ and $\left.{ }^{32} \mathrm{P}\right] \mathrm{TTP}(3000 \mathrm{Ci} / \mathrm{mmol})$ were supplied by New England Nuclear (Boston, MA), while [32 P]ddATP $(3000 \mathrm{Ci} / \mathrm{mmol})$ was obtained from Amersham. HAP was obtained from Bio-Rad (Richmond, CA); DNA molecular weight markers, terminal transferase and the Klenow fragment of DNA polymerase I were obtained from Boehringer Mannheim Biochemicals (Indianapolis, IN). All cell culture supplies were acquired from the Grand Island Biological Co. (Grand Island, NY). NuSieve agarose was supplied by FMC Biochemicals (Rockland, ME).

Cells. L1210 leukemia cells were grown in Fischer's medium supplemented with $10 \%$ horse serum as previously described [4]. Exponentially growing cells were used in these studies.

Cell lysis. The technique was performed as a modification of that previously described [13]. L1210 cells $\left(1 \times 10^{7}\right.$ cells/determination $)$ were treated with drugs, pulse labeled with $35 \mu \mathrm{Ci}\left[{ }^{3} \mathrm{H}\right] \mathrm{dTh}$ for $10 \mathrm{~min}$, and then were either harvested immediately or pelleted, resuspended in medium with or without drug, and subsequently incubated at $37^{\circ}$. At the indicated time, cells were collected by centrifugation and resuspended in $0.06 \mathrm{M} \mathrm{NaOH}$ and kept for $30 \mathrm{~min}$ on ice in the dark. The lysate was neutralized with a solution that yielded $7 \mathrm{mM} \mathrm{PO}_{4}, \mathrm{pH} 7.5$, $5 \mathrm{mM}$ EDTA and $0.3 \%$ Sarkosyl.

HAP chromatography. Nucleotides, ssDNA and dsDNA were separated utilizing a batch chroma- tography method [14]. Cell lysates were adjusted to $10 \%$ formamide, combined with $0.6 \mathrm{~g} \mathrm{HAP}$ (which had been boiled previously in $10 \mathrm{mM} \mathrm{KPO}_{4}, \mathrm{pH} 7$ ), and subsequently incubated with mixing at $60^{\circ}$ for $15 \mathrm{~min}$. The matrix was pelleted, resuspended in $10 \mathrm{mM} \mathrm{KPO}_{4}, \mathrm{pH} 7$, with $20 \%$ formamide and incubated for $10 \mathrm{~min}$ at $60^{\circ}$ with mixing. The HAP containing DNA was collected by centrifugation and removed from the supernatant, which consisted primarily of nucleotides and cell debris. The elution of ssDNA and dsDNA was achieved as above in $0.16 \mathrm{M}$ and $0.5 \mathrm{M}$ phosphate buffer, $\mathrm{pH} 7$, containing $20 \%$ formamide, respectively. The amount of radiolabel incorporated into DNA was assessed by liquid scintillation spectrometry.

Agarose gel electrophoresis. Samples with equal amounts of ssDNA from HAP were electrophoresed in $2.5 \%$ NuSieve agarose gels with TAE buffer (40 $\mathrm{mM}$ Tris acetate, $1 \mathrm{mM}$ EDTA) employing an LKB Multiphor apparatus at constant voltage $(3.5 \mathrm{~V} / \mathrm{cm})$. Molecular weight markers (1/Hind III), prepared with $\left[{ }^{3} \mathrm{H}\right] \mathrm{TTP}$ and the Klenow fragment of DNA polymerase I, were denatured with $90 \%$ formamide just prior to electrophoresis. Following the run, the gel was washed for $60 \mathrm{~min}$ at $4^{\circ}$ with $5 \%$ trichloroacetic acid (TCA), rinsed with water, and sliced ( $2 \mathrm{~mm}$ ). Each slice was dissolved with TS2 (RPI, Mount Prospect, IL) overnight and neutralized with glacial acetic acid; the amount of label was determined by scintillation spectrometry.

Analysis of available 3'-termini. Phosphate was removed from hydroxylapatite fractions containing dsDNA by extensive dialysis. Recessed $3^{\prime}$-ends $(1 \mu \mathrm{g}$ dsDNA/sample) were labeled with [ $\left.{ }^{32} \mathrm{P}\right] \mathrm{TTP}$ using the Klenow fragment as suggested by the supplier. Aliquots of each sample were spotted on Whatman $3 \mathrm{MM}$ filter discs, and the DNA was precipitated with $5 \% \mathrm{TCA} / 1 \% \mathrm{NaPP}_{\mathrm{i}}$.

Available $3^{\prime}$-ends in purified ssDNA fractions were labeled with $\left[{ }^{32} \mathrm{P}\right] \mathrm{ddATP}$ using terminal transferase as described by the supplier. Equal amounts of DNA $(0.5 \mu \mathrm{g} / \mathrm{sample})$ were incubated with label and enzyme for $2 \mathrm{hr}$, and the reaction was stopped by the addition of EDTA, glycogen and TCA. The precipitates were collected by filtration on nitrocellulose filters and washed with $5 \% \mathrm{TCA} / 1 \%$ NaPP.

The incorporation of label in both experiments was quantitated by scintillation spectrometry, and appropriate blanks were subtracted. The DNA content of each fraction was determined utilizing diaminobenzoic acid as described by Kapp et al. [15].

\section{RESULTS}

Hydroxylapatite chromatography. The limited alkaline cell lysis procedure, as described by Lonn and Lonn [13], denatures DNA pieces, including replicative intermediates, up to 20,000 bases in length into ssDNA, while bulk DNA reanneals to predominantly dsDNA upon neutralization. The batch HAP method allows the preparative separation of the nucleotide, ssDNA, and dsDNA populations generated by the lysis method.

To ensure that the DNA present in the ssDNA 
Table 1. Soft agar cloning of L1210 cells

\begin{tabular}{lc}
\hline Control & $\begin{array}{c}\text { Cloning efficiency } \\
\text { (\% of control) }\end{array}$ \\
$2.5 \mu \mathrm{M} \mathrm{3} 3^{r}-\mathrm{NH}_{2}$-ddCyd & 100 \\
$0.25 \mu \mathrm{g} / \mathrm{mL}^{\prime}$ aphidicolin & $95.9 \pm 0.8$ \\
$20 \mu \mathrm{M} 3^{\prime}-\mathrm{NH}_{2}$-ddCyd & $100.6 \pm 0.6$ \\
$0.5 \mu \mathrm{g} / \mathrm{mL}$ aphidicolin & $53.3 \pm 4.0$ \\
\hline
\end{tabular}

L1210 cells were treated with drug for $9.5 \mathrm{hr}$ and immediately suspended in $0.25 \%$ agar in medium supplemented with $15 \%$ horse serum and incubated at $37^{\circ}$ for 8-10 days. Approximately 100 colonies per control plate were counted with a cloning efficiency of $75 \%$. Data represent the means \pm SEM of three experiments, each with an $\mathbf{N}=8$.

fractions is not the result of fragmentation of bulk dsDNA, and that the majority of ssDNA is eluted in the ssDNA fractions, control experiments were performed with L 1210 cells prelabeled for $18 \mathrm{hr}$ with $\left[{ }^{14} \mathrm{C}\right] \mathrm{dThd}$. Following a 4 -hr chase to remove any labeled nucleotides, cells were pulse labeled with $\left[{ }^{3} \mathrm{H}\right] \mathrm{dTh}$ to label ssDNA and lysed; then the DNA was separated by the HAP method. Greater than $90 \%$ of the ${ }^{14} \mathrm{C}$ eluted in the dsDNA fractions (data not shown).

Although the same control experiments were not performed for cells treated with $3^{3}-\mathrm{NH}_{2}$-ddCyd, the same separation of ssDNA and dsDNA wonld be expected since it has been shown that a similar exposure to $3^{\prime}-\mathrm{NH}_{2}$-ddCyd did not lead to frag. mentation (or even nicking) of parental dsDNA as demonstrated by both alkaline and neutral sucrose gradient centrifugation [7]. This is of particular importance in light of the evidence that chemotherapeutic drugs can induce nucleosomal, dsDNA fragmentation associated with apoptotic cell death. It has been shown that ara-C treatment of HL-60 cells (a cell line susceptible to drug-induced nucleosomal DNA fragmentation) did not show a "DNA ladder" until at least 24-hr exposure [16]. Although experiments were not performed to look for characteristics of apoptotic cell death, no evidence of dsDNA breaks has been observed under the treatment conditions utilized in these experiments.

To compare the effects of $3^{\prime}-\mathrm{NH}_{2}-\mathrm{ddCyd}$ and aphidicolin on the synthesis and elongation of DNA replicative intermediates, concentrations were selected that inhibited incorporation of $\left[{ }^{3} \mathrm{H}\right] \mathrm{dThd}$ into acid-precipitable material to the same extent.
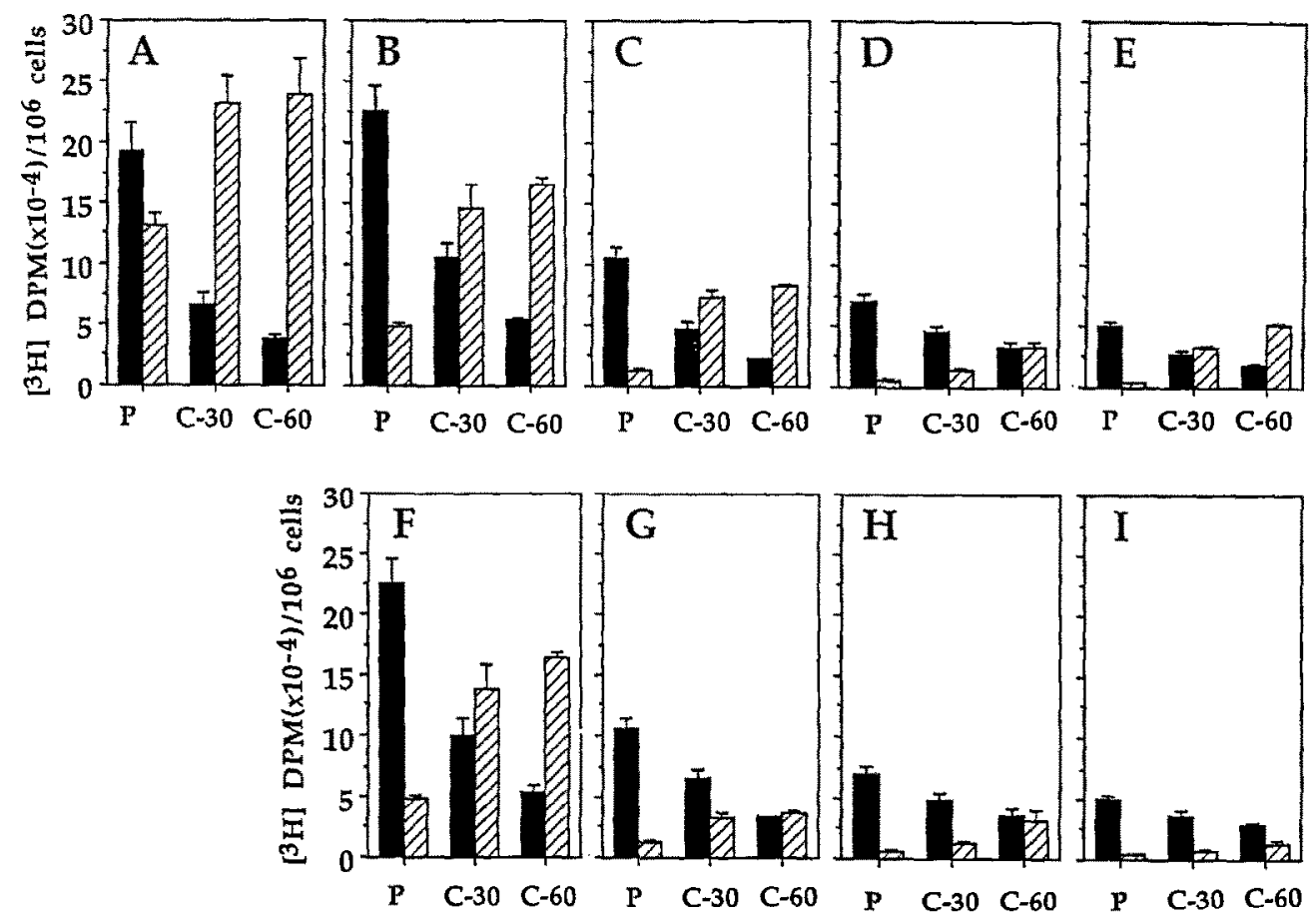

Fig. 1. Labeling of ssDNA (solid bars) and dsDNA (hatched bars) hydroxylapatite fractions. L1210 cells $\left(10^{7} /\right.$ determination) were pulse labeled with [ $\left.{ }^{3} \mathrm{H}\right] \mathrm{dThd}$ for $10 \mathrm{~min}$ following a $9.5-\mathrm{hr}$ exposure to saline (A);2.5 $\mu \mathrm{M} \mathrm{3}^{\prime}-\mathrm{NH}_{2}$-duCyd (B and F);0.25 $\mu \mathrm{g} / \mathrm{mL}$ aphidicolin (C and $\mathrm{G}$ ); $20 \mu \mathrm{M} 3^{\prime}-\mathrm{NH}_{2}$-ddCyd $(\mathrm{D}$ and $\mathrm{H})$; and $0.5 \mu \mathrm{g} / \mathrm{mL}$ aphidicolin (E and I). Samples were harvested immediately (P), or were resuspended in medium plus $(\mathrm{F}-\mathrm{I})$ or minus $(\mathrm{A}-\mathrm{E})$ drug and chased for either $30 \mathrm{~min}(\mathrm{C}-30)$ or $60 \mathrm{~min}$ (C-60) prior to harvest. Cell lysis and separation of ssDNA and dsDNA were performed as described in Materials and Methods. Data are expressed as the total dpm in the ssDNA and dsDNA fractions and represent the average of three experiments $\pm S E M$, except for control, $20 \mu \mathrm{M} 3^{\prime}-\mathrm{NH}_{2}$-ddCyd, and $0.5 \mu \mathrm{g} / \mathrm{mL}$ aphidicolin samples where $\mathrm{N}=5$. 

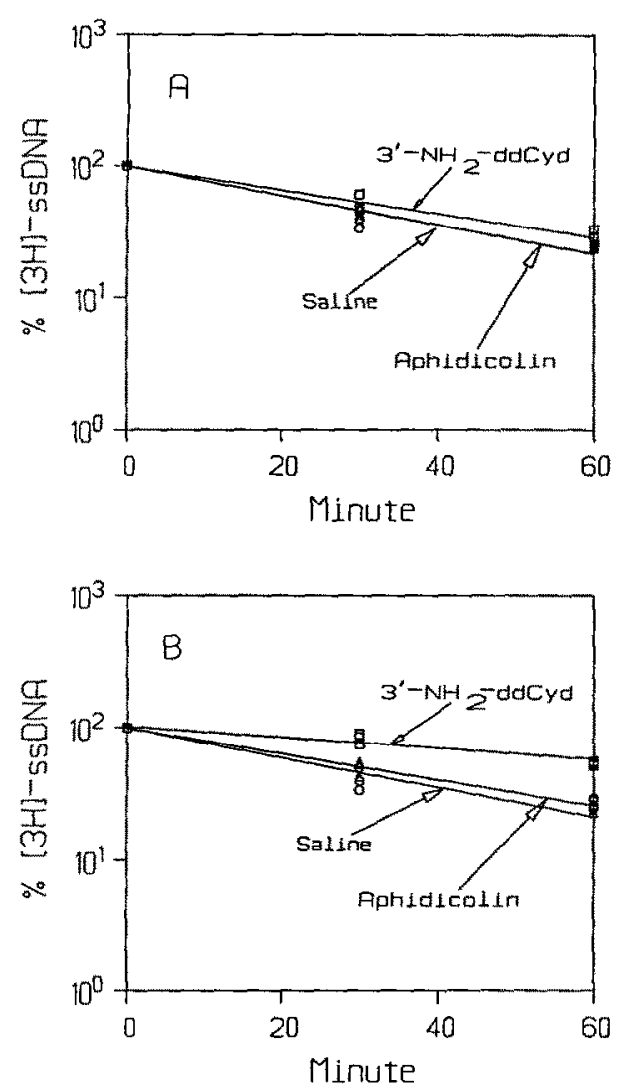

Fig. 2. Rates of elongation of $\$$. intermediates to dsDNA. Labeled L1210 DNA was separated into ssDNA and dsDNA populations as described in Fig. 1 and Materials and Methods. The samples were treated for $9.5 \mathrm{hr}$ with $(A)$ saline $(-O-0.25 \mu \mathrm{g} / \mathrm{mL}$ aphidicolin $(-\triangle-)$, and $2.5 \mu \mathrm{M} 3^{\prime}-\mathrm{NH}_{2}$-ddCyd (C) or (B) saline $(-O-0.5 \mu \mathrm{g} / \mathrm{mL}$ aphidicolin $(-\Delta-)$, or $20 \mu \mathrm{M} 3^{\prime}-\mathrm{NH}_{2}$-ddCyd ( $\left.\square\right)$ prior to pulse labeling the DNA. The percent label cluting in the ssDNA fractions was plotted versus time of chase in the absence of the drugs, and the data at $\mathrm{t}=0$ were normalized to $100 \%$. Lines were fitted to the data using a non-linear regression analysis program as in Table 2 . The first-order rate equation: $L=$ $\mathrm{L}_{\mathrm{o}} e^{-k t}$, where $\mathrm{L}_{\mathrm{o}}$ and $\mathrm{L}$ are the percent labeled ssDNA at the end of the pulse label and subsequent chase, respectively. The rate constant is $k$ and $t$ is time.

After a 9.5-hr exposure, aphidicolin, at concentrations of 0.25 and $0.5 \mu \mathrm{g} / \mathrm{mL}$, inhibited DNA synthesis 70 and $90 \%$, respectively, while 2.5 and $20 \mu \mathrm{M} 3$ ' $-\mathrm{NH}_{2}$-ddCyd inhibited it 60 and $90 \%$ (data not shown). In parallel experiments, neither concentration of aphidicolin was found to inhibit cell viability as determined by soft agar cloning (Table 1). In contrast, while treatment with $2.5 \mu \mathrm{M} 3^{\prime}-\mathrm{NH}_{2}-$ ddCyd did not affect cell survival, exposure to $20 \mu \mathrm{M} \quad 3^{\prime}-\mathrm{NH}_{2}$-ddCyd decreased cell viability by approximately $50 \%$.

Figure 1 summarizes the effects of $3^{\prime}-\mathrm{NH}_{2}$-ddCyd and aphidicolin on the distribution of labeled DNA in the HAP fractions following a 10 -min incubation of cells with $\left[{ }^{3} \mathrm{H}\right] \mathrm{dTh}$. The data are expressed as the total label in SsDNA and dsDNA fractions per
$10^{6}$ cells. Aphidicolin and $3^{\prime}-\mathrm{NH}_{2}$-ddCyd at both concentrations inhibited the pulse labeling of dsDNA, while increasing the relative labeling of the ssDNA populations. Note, however, that compared with untreated cells, the analogs led to lesser inhibition of $\left[{ }^{3} \mathrm{H}\right] \mathrm{d}$ Thd incorporation during a 10 min pulse label than observed in the determinations of DNA synthesis inhibition discussed above. This is probably due to the different number of cells used. The latter assay was not corrected for cell number, while the same number of cells was utilized in the HAP procedure. This would not be expected to alter the $\left[{ }^{3} \mathrm{H}\right] \mathrm{dTh}$ Thtake of untreated cells, but $3^{\prime}-\mathrm{NH}_{2}-$ ddCyd-treated cells accumulate in $S$ phase [7] and would be expected to incorporate more label with the additional cells required to equal the untreated condition.

Pulse/chase experiments, with the chase occurring in the presence or the absence of the drug, were performed to evaluate drug effects on DNA elongation. The amount of label associated with the ssDNA or dsDNA fractions was calculated at each time point (Fig. 1), and the percent of DNAassociated label that eluted in the ssDNA fractions was determined, normalized and plotted versus duration of chase (Fig. 2). From these plots, the rates of elongation of ssDNA to dsDNA can be determined (note that Fig. 2 only shows plots obtained from experiments chased in the absence of drug), and the half-life of elongation of ssDNA was calculated from the slopes (Table 2).

Untreated cells rapidly elongated replicative intermediates to dsDNA with greater than 75 and $85 \%$ of label in dsDNA fractions after a 30 - and $60-$ min chase, respectively. If drug was removed prior to chase, samples treated with either concentration of aphidicolin as well as $2.5 \mu \mathrm{M} 3^{\prime}-\mathrm{NH}_{2}$-ddCyd readily elongated SsDNA to dsDNA at rates similar to untreated cells. However, at $20 \mu \mathrm{M} 3^{t}-\mathrm{NH}_{2}-$ ddCyd, the majority of the replicative intermediates (greater than $50 \%$ of total label) remained in the ssDNA fractions, even after a 60 -min chase following drug removal. The rate of elongation of ssDNA under these conditions was one-third that exhibited by untreated cells (Table 2).

When drug was maintained during the chase, cells exposed to aphidicolin showed a sustained inhibition of elongation as compared with drug removal (Fig. 1; Table 2). In contrast, the continued presence of $3^{\prime}-\mathrm{NH}_{2}$-ddCyd yielded the same rate of elongation as in the absence of the drug.

Agarose gel electrophoresis. Using NuSieve agarose, small DNA pieces can be resolved and the size distribution of the labeled fragments present in the pooled ssDNA HAP fractions can be analyzed. To compare different conditions, the percent total counts for each sample were plotted (Figs. 3 and 4). Under all conditions, two predominant peaks of radioactivity were present, one peak at approximately 200 bases (Okazaki fragments) and one at 10,00020,000 bases (replicons). Markers indicating the mobility of labeled ssDNA of 9600 and 246 bases are shown. Under all conditions, there existed a range of sizes both greater than and less than the 246 base marker in the lower molecular weight peak of DNA. However, the resolution of labeled DNA 
Table 2. Rates of elongation of ssDNA replicative intermediates

\begin{tabular}{lcccccc}
\hline & Chase & $\mathrm{N}$ & \multicolumn{1}{c}{$k$} & $\mathrm{SD}$ & $r^{2}$ & $\mathrm{~T}_{1 / 2}(\min )$ \\
\hline Control & & 5 & 0.02813 & 0.00203 & 0.9895 & 24.6 \\
$2.5 \mu \mathrm{M} 3^{\prime}-\mathrm{NH}_{2}$-ddCyd & - & 3 & 0.02078 & 0.00184 & 0.9928 & 33.4 \\
& + & 3 & 0.0279 & 0.00257 & 0.9860 & 33.3 \\
$0.25 \mu \mathrm{g} / \mathrm{mL}$ Aphidicolin & - & 3 & 0.02563 & 0.00111 & 0.9980 & 27.0 \\
$20 \mu \mathrm{M} 3^{\prime}-\mathrm{NH}_{2}$-ddCyd & + & 3 & 0.01014 & 0.00046 & 0.9993 & 68.3 \\
& - & 5 & 0.009187 & 0.00082 & 0.9955 & 75.4 \\
$0.5 \mu \mathrm{g} / \mathrm{mL}$ Aphidicolin & + & 3 & 0.007972 & 0.00126 & 0.9944 & 86.9 \\
& - & 5 & 0.02156 & 0.00096 & 0.9965 & 32.1 \\
\hline
\end{tabular}

Cells were treated as in Fig. 1 with the chase occurring in the absence $(-)$ or the presence $(+)$ of the drug. Separation of ssDNA and dsDNA was performed as described in Materials and Methods, and the percent $\mathrm{dpm}$ in the ssDNA fractions was determined. Plots of the percent ssDNA vs time were generated (Fig. 2), and lines were fit to the data using a non-linear regression analysis program. Rate constants and variability were determined from the fitted lines using the equation $L=L_{0} \mathrm{e}^{-k t}$.
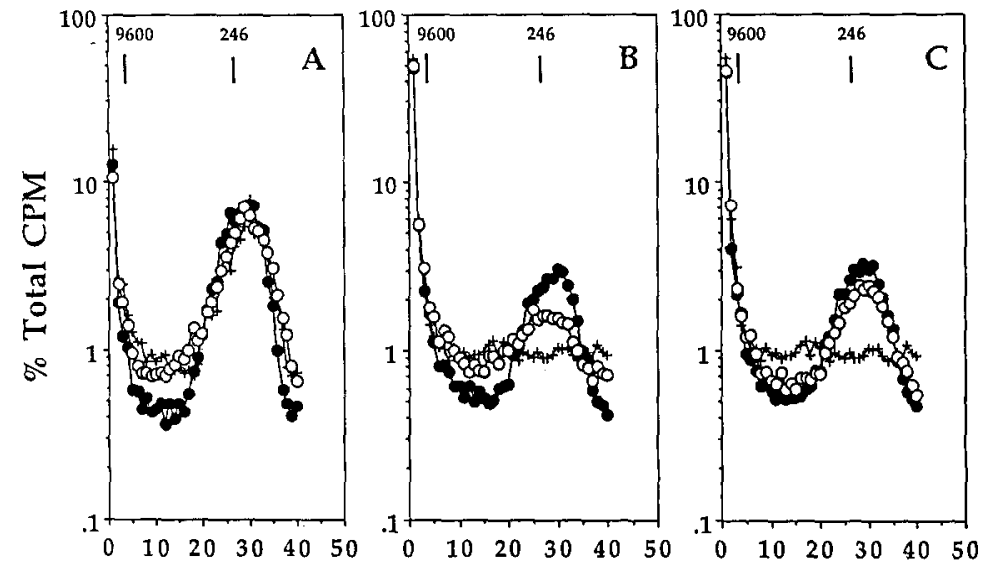

Gel Slice

Fig. 3. Agarose gel electrophoretic separation of ssDNA hydroxylapatite fractions after low drug exposure. Pooled ssDNA fractions from control cells $(+)$, and cells treated with $2.5 \mu \mathrm{M} 3^{\prime}-\mathrm{NH}_{2}$-ddCyd (O) or $0.25 \mu \mathrm{g} / \mathrm{mL}$ aphidicolin $(\mathrm{O})$ were separated by agarose gel electrophoresis, as described in Materials and Methods. The samples analyzed correspond to those harvested immediately following the pulse label (A), those chased $30 \mathrm{~min}$ in the absence of both drug and label (B), or those chased $30 \mathrm{~min}$ in the presence of the drug and the absence of label (C). Data represent the average of two separate experiments.

fragments did not allow a firm demarcation of molecular weights within the lower molecular weight peak.

Exposure to low concentrations of aphidicolin $(0.25 \mu \mathrm{g} / \mathrm{mL})$ or $3^{\prime}-\mathrm{NH}_{2}$-ddCyd $(2.5 \mu \mathrm{M})$ led to relative labeling of both populations of DNA similar to that in untreated cells following a 10-min pulse (Fig. 3A). However, following a 30-min chase in the absence of the drug (Fig. 3B), the aphidicolintreated cells elongated the small DNA fragments more rapidly than those from cells exposed to $2.5 \mu \mathrm{M}$ $3^{\prime}$ - $\mathrm{NH}_{2}$-ddCyd, although both drug-treated samples were elongated to a lesser degree than control cultures. There also appeared to be a slightly smaller size distribution of the low molecular weight DNA fragments in the $3^{\prime}-\mathrm{NH}_{2}$-ddCyd-treated cells as compared with those exposed to aphidicolin. When the chase was performed in the presence of the drug (Fig. 3C), cells treated with both $0.25 \mu \mathrm{g} / \mathrm{mL}$ aphidicolin and $2.5 \mu \mathrm{M} \quad 3^{\prime}-\mathrm{NH}_{2}$-ddCyd elongated pulse-labeled fragments to a similar degree, but much less than that observed in untreated cells.

In contrast, when the pooled ssDNA fractions from cells treated with either $0.5 \mu \mathrm{g} / \mathrm{mL}$ aphidicolin or $20 \mu \mathrm{M} 3$ '- $\mathrm{NH}_{2}$-ddCyd were separated by agarose gel electrophoresis, the relative labeling of DNA $10-20 \mathrm{~kb}$ in length in drug-treated cells was less than that in control cells (Fig. 4A). In addition, the percent label in the peak of DNA at approximately 200 bases appeared to be equal for drug-treated 


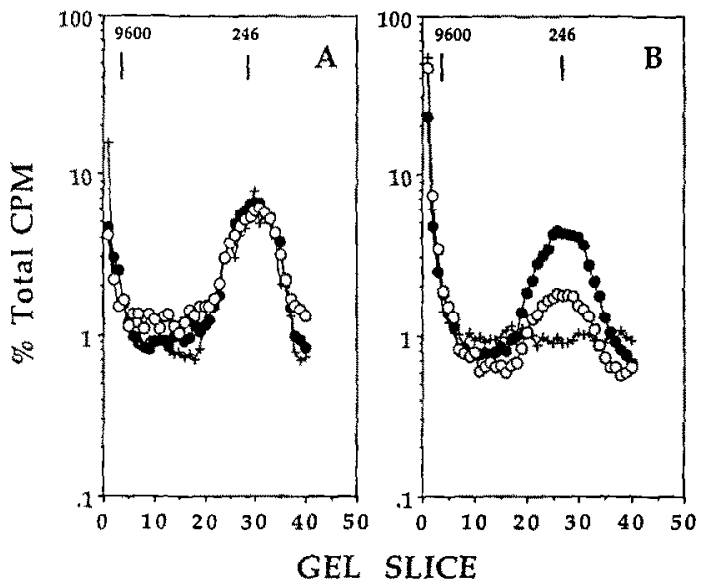

Fig. 4. Agarose gel electrophoretic separation of ssDNA hydroxylapatite fractions after high drug exposure. Pooled ssDNA fractions from control cells $(+)$, and cells treated with $20 \mu \mathrm{M}$ 3'- $\mathrm{NH}_{2}$-ddCyd (O) or $0.5 \mu \mathrm{g} / \mathrm{mL}$ aphidicolin $(O)$ were separated by agarose gel electrophoresis, as described in Materials and Methods. The samples analyzed correspond to those harvested immediately following the pulse labcl (A) and those chased $30 \mathrm{~min}$ in the absence of both drug and label (B). Data represent the average of two separate experiments. and control cultures. Pulse/chase experiments demonstrated that following a 30 -min chase in the absence of the drug, cultures exposed to $0.5 \mu \mathrm{g} / \mathrm{mL}$ aphidicolin readily elongated the fragments to higher molecular weight DNA nearly equal to that seen under control conditions (Fig. 4B). However, treatment with $20 \mu \mathrm{M} 3^{\prime}-\mathrm{NH}_{2}$-ddCyd demonstrated much less elongation upon a 30 -min chase in the absence of the drug, although there was a decrease in the relative labeling of the Okazaki fragment peak and an increase in the label associated with the 10$20 \mathrm{~kb}$ peak (Fig. 4B).

To quantitate further the distribution of ssDNA intermediates as detected by agarose gel electrophoresis, the total dpm under each peak were determined for each sample after adjustment for quench in each slice and subtraction of background counts (Fig. 5). The data supported the conclusions from the plots of the gel, but also showed more subtle differences in the distributions of label between the two peaks that were not readily apparent from the graphs. It can be seen that, in untreated cells, nearly $100 \%$ of pulse-labeled Okazaki-sized fragments were elongated to replicon-sized DNA after a 30-min chase. Treatment with the low concentrations of the two drugs led to an
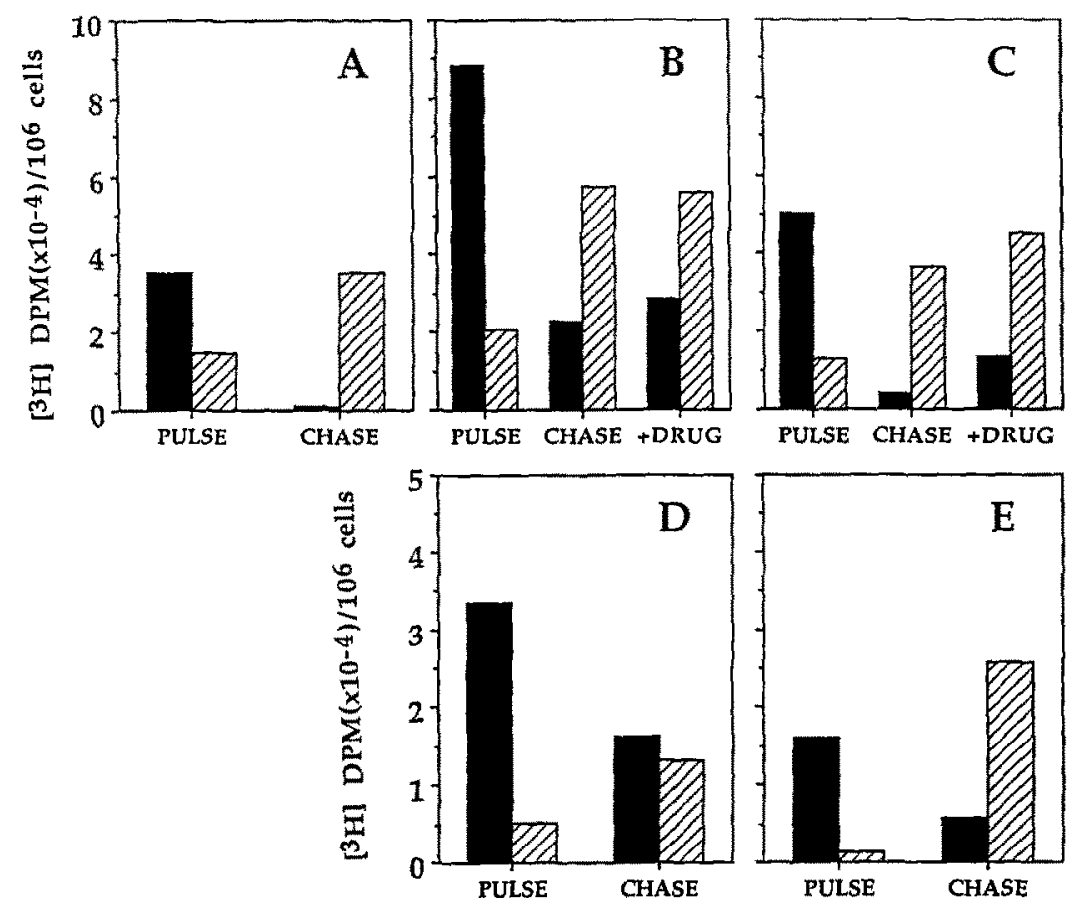

Fig. 5. Distribution of labeled replication intermediates in ssDNA fractions: Area under the curve. Aliquots of pooled ssDNA fractions [including those from samples pulse labeled (PULSE) and those chased $30 \mathrm{~min}$ in the presence (+DRUG) or absence (CHASE) of the drugl were separated on NuSieve agarose gels as described in Materials and Methods [control (A); $2.5 \mu \mathrm{M} 3{ }^{\prime}-\mathrm{NH}_{2}$-ddCyd (B); $0.25 \mu \mathrm{g}$ / mL aphidicolin (C); $20 \mu \mathrm{M} 3^{\prime}-\mathrm{NH}_{2}$-ddCyd (D); and $0.5 \mu \mathrm{g} / \mathrm{mL}$ aphidicolin (E)]. From the plots in Figs. 3 and 4 , the total label under each peak [LMW (solid bars) = Okazaki fragment size ( 2200 bases); HMW (hatched bars) $=$ replicon size $(10-20 \mathrm{~kb})]$ was determined. Background cpm for each slice were determined from lanes without sample loaded and were subtracted from each sample; the dpm were calculated after adjustment for quench. Gel slice No. 12 (see Figs. 3 and 4) was designated as the demarcation between HMW and LMW DNA populations. Data represent the average of two separate 
Table 3. Incorporation of TTP into dsDNA from HAP fractions

\begin{tabular}{lcc}
\hline & $\begin{array}{c}\text { TTP } \\
\text { (pmol/ } \mu \mathrm{g} \mathrm{DNA})\end{array}$ & $\begin{array}{c}\% \text { of } \\
\text { Control }\end{array}$ \\
\hline Control & $1.30 \pm 0.08$ & 100 \\
$2.5 \mu \mathrm{M} \mathrm{3} 3^{\prime}-\mathrm{NH}_{2}$-ddCyd & $1.21 \pm 0.06$ & 93.1 \\
$0.25 \mu \mathrm{g} / \mathrm{mL} \mathrm{Aphidicolin}^{\prime}$ & $1.23 \pm 0.04$ & 94.6 \\
$20 \mu \mathrm{M} 3^{\prime}-\mathrm{NH}_{2}$-ddCyd & $\mathbf{0 . 6 5} \pm 0.04$ & $\mathbf{5 0 . 0}$ \\
$0.5 \mu \mathrm{g} / \mathrm{mL} \mathrm{Aphidicolin}$ & $1.26 \pm 0.06$ & 96.9 \\
\hline
\end{tabular}

DNA $(1 \mu \mathrm{g} /$ determination) was incubated with the Klenow fragment of DNA polymerase I $(6 \mathrm{U})$ for $30 \mathrm{~min}$ as described in Materials and Methods. An aliquot was spotted on Whatman 3MM discs, and the DNA was precipitated with $5 \% \mathrm{TCA} / 1 \% \mathrm{NaPP}_{\mathrm{i}}$. Data represent the averages of duplicate samples from two experiments \pm SEM.

accumulation of label in the Okazaki fragment-sized peak as depicted in the large accumulation of the total label in this peak (Fig. 5). Chase of these fragments to replicon sized DNA $(10,000-20,000$ bases), both in the presence and the absence of the drugs, was less in $3^{\prime}-\mathrm{NH}_{2}$-ddCyd-treated cells than in aphidicolin-treated cells. This was most evident in the disparate decrease of label associated with the Okazaki fragment-sized peak upon a 30-min chase in the absence of drug for aphidicolin (12-fold decrease) and $3^{\prime}-\mathrm{NH}_{2}$-ddCyd (<4-fold decrease).

Exposure to $0.5 \mu \mathrm{g} / \mathrm{mL}$ aphidicolin strongly inhibited the relative and total labeling of the high molecular weight peak, and upon chase in the absence of aphidicolin, Okazaki fragment-sized DNA was rapidly elongated to higher molecular weight DNA. The inhibition of relative and total labeling of the high molecular weight peak in the presence of $20 \mu \mathrm{M} 3^{\prime}-\mathrm{NH}_{2}$-ddCyd was similar to that with $0.5 \mu \mathrm{g} / \mathrm{mL}$ aphidicolin. In contrast to aphidicolin, however, low molecular weight DNA from $20 \mu \mathrm{M} 3^{\prime}-\mathrm{NH}_{2}$-ddCyd-treated cells was poorly elongated in the absence of the drug with greater than $50 \%$ remaining as Okazaki fragment-sized pieces (Figs. 4B and 5).

Assay of available 3 -termini. To determine the ability of DNA from drug-treated samples to serve as a template for further DNA synthesis, DNA was purified from pooled dsDNA fractions and incubated with the Klenow fragment of DNA polymerase I (Table 3). In experiments using equal amounts of DNA, the Klenow catalyzed incorporation of $\left[{ }^{32} \mathrm{P}\right]-$ TTP into DNA from cells exposed to $20 \mu \mathrm{M} 3^{\prime}-\mathrm{NH}_{2}$ ddCyd for $9.5 \mathrm{hr}$ was $50 \%$ that of control DNA. DNA from cells treated with aphidicolin and $2.5 \mu \mathrm{M}$ $3^{\prime}-\mathrm{NH}_{2}$-ddCyd were not different from control.

Further investigation of $3^{\prime}-\mathrm{NH}_{2}$-ddCyd-induced inactivation of available $3^{\prime}$-ends focused on the nascent DNA replicative intermediates. Available $3^{\prime}$-ends in DNA purified from pooled ssDNA fractions were labeled with $\left[{ }^{32} \mathrm{P}\right]$ ddATP using terminal transferase. Since only one nucleotide can be added per available 3 -terminus, the level of analog incorporation can be used as a direct measure of the number of available ends under each condition. In vitro, a single incorporated $3^{\prime}-\mathrm{NH}_{2}$-ddCyd
Table 4. Incorporation of ddATP into ssDNA from ssDNA fractions

\begin{tabular}{lcc}
\hline & $\begin{array}{c}\text { ddATP } \\
\text { (pmol/0.5 } \mu \mathrm{g} \mathrm{DNA})\end{array}$ & $\begin{array}{c}\text { \% of } \\
\text { Control }\end{array}$ \\
\hline Control & $8.56 \pm 0.15$ & 100 \\
$2.5 \mu \mathrm{M} 3^{\prime}-\mathrm{NH}_{2}$-ddCyd & $9.23 \pm 0.21$ & 107.8 \\
$0.25 \mu \mathrm{g} / \mathrm{mL} \mathrm{Aphidicolin}^{\prime}$. & $9.60 \pm 0.66$ & 112.1 \\
$20 \mu \mathrm{M} \mathrm{3}$ '- $\mathrm{NH}_{2}$-ddCyd & $4.93 \pm 0.29$ & 57.6 \\
$0.5 \mu \mathrm{g} / \mathrm{mL}$ Aphidicolin & $8.64 \pm 0.66$ & 100.1 \\
\hline
\end{tabular}

DNA $(0.5 \mu \mathrm{g} /$ determination $)$ was incubated with terminal transferase $(20 \mathrm{U})$ for $120 \mathrm{~min}$ as described in Materials and Methods. The DNA was precipitated and collected on nitrocellulose filters that were washed with $5 \% \mathrm{TCA} / 1 \% \mathrm{NaPP}_{\mathrm{i}}$. Data represent the averages of duplicate samples from two experiments \pm SEM.

molecule was sufficient to block further synthesis by terminal transferase on a ssDNA substrate [17]. Using ssDNA from untreated cells, approximately $8.5 \mathrm{pmol}$ of ddATP was incorporated, whereas almost 5 pmol ( $58 \%$ of control) was incorporated into ssDNA from samples exposed to $20 \mu \mathrm{M} 3^{\prime}-\mathrm{NH}_{2-}$ ddCyd (Table 4). The level of ddATP incorporation into DNA from samples treated with $2.5 \mu \mathrm{M} 3^{\prime}$ $\mathrm{NH}_{2}$-ddCyd or either concentration of aphidicolin was not different from that of control.

\section{DISCUSSION}

$3^{\prime}-\mathrm{NH}_{2}$-ddCyd is a deoxycytidine analog that inhibits DNA polymerase $\alpha$ in vitro [7]. Although no incorporated analog was detected in previous studies using cells in culture [7], these experiments were limited by the use of tritiated $3^{\prime}-\mathrm{NH}_{2}$-ddCyd of very low specific activity $(<0.5 \mathrm{Ci} / \mathrm{mmol})$ or the use of unlabeled analog in $\left.{ }^{32} \mathrm{P}\right]$ orthophosphateloaded cells. In addition, the shorter exposure ( $5.5 \mathrm{hr}$ ) of cells to drug coupled with the 5-fold lower binding affinity of $3^{\prime}-\mathrm{NH}_{2}$-ddCyd for dCyd kinase relative to ara-C [5], may have yielded a level of incorporated labeled drug insufficient for detection. The detection of ara-C was made possible not only because of the high specific activity $(26 \mathrm{Ci} / \mathrm{mmol})$, but also because incorporation of ara-CMP residues is predominantly internucleotide [18], which would allow greater accumulation of label (per unit time) compared to a chain terminating agent. It is also possible that incorporated $3^{\prime}-\mathrm{NH}_{2}$-ddCMP could have been removed by DNA repair enzymes, especially during the early stage of cell harvest where repair processes might be expected to continue during the collection and washing of cells. In subsequent experiments using alkaline sucrose gradient centrifugation, $3^{\prime}-\mathrm{NH}_{2}$-ddCyd demonstrated inhibitory properties of newly synthesized DNA that were similar to those induced by ara-C, suggesting a mechanism other than competitive inhibition of DNA polymerase [7].

In the present study, the question of whether 3 '$\mathrm{NH}_{2}$-ddCyd acts to inhibit DNA synthesis by inhibition of DNA polymerase or via incorporation into DNA was approached by the use of limited alkaline lysis [13] to examine replicative intermediates 
at a particular point in time without regard to subsequent DNA repair and by the employment of HAP chromatography to enrich specific DNA populations for further analysis.

If competitive inhibition of DNA polymerase is the sole mechanism by which $3^{\prime}-\mathrm{NH}_{2}$-ddCyd is inhibiting DNA synthesis, the prolonged inhibition upon removal of the drug (Table 2) suggests that $3^{\prime}$ $\mathrm{NH}_{2}$-ddCTP has a longer retention time in the nucleus than aphidicolin. Although known to be readily reversible upon removal, aphidicolin is a potent competitive inhibitor of purified DNA polymerase $\alpha$ with a $K_{i}$ approximately 50 times less than the $K_{m}$ of dCTP [19]. The $K_{i}$ of $3^{\prime}-\mathrm{NH}_{2}$-ddCTP $(9.6 \mu \mathrm{M})[7]$, however, is about 5-fold higher than the $K_{m}$ of dCTP, the ratio of which, as shown for ara-CTP [9], suggests that $3^{\prime}-\mathrm{NH}_{2}$-ddCTP should be a weak inhibitor of DNA polymerase $\alpha$. It has been shown that ara-CTP readily accumulates in the nucleus of L1210 cells, and its half-life is on the order of 1 to $1.5 \mathrm{hr}$ [20].

The amount of $3^{\prime}-\mathrm{NH}_{2}$-ddCTP formed and its halflife in the nucleus have not been determined, and the possibility exists that sufficient $3^{\prime}-\mathrm{NH}_{2}$-ddCTP remains in the nucleus to account for the observed inhibition of DNA synthesis and subsequent chain elongation. However, if one assumes a half-life for $3^{\prime}-\mathrm{NH}_{2}$-ddCTP similar to that of ara-CTP [20] and a loss of $3^{\prime}-\mathrm{NH}_{2}$-ddCTP with time, the chase in the absence of drug (Fig. 1) would be expected to yield a lower level of label in ssDNA and a higher level in dsDNA as compared with the chase with the drug present. Although this change is what was seen with aphidicolin, no difference in the distribution of label was observed with either concentration of 3 ' $-\mathrm{NH}_{2}$ ddCyd. Thus, if $3^{\prime}-\mathrm{NH}_{2}$-ddCyd is a pure competitive inhibitor like aphidicolin, one would expect to see, as the level of $3^{\prime}-\mathrm{NH}_{2}$-ddCTP declines, a reduction in inhibition of DNA polymerase with a subsequent increase in the rate of elongation. This was not observed for the amino analog even though the level of competing dCTP is maintained during the initial exposure [7] and increases under conditions that induce cell lethality $[4,7]$. Moreover, results from in vitro addition of nucleotides to DNA isolated from drug-treated cells (Tables 3 and 4) are strong support for an alternative mechanism for inhibition of DNA synthesis by $3^{\prime}-\mathrm{NH}_{2}$-ddCyd. These observations suggest that aphidicolin is inhibiting cellular DNA synthesis through competitive interactions with DNA polymerase, whereas $3^{\prime}-\mathrm{NH}_{2}$-ddCTP inhibits through a different mechanism, possibly involving the incorporation of the analog into the DNA.

Chidgeavadze et al. [10] have proposed that, in vitro, $3^{\prime}-\mathrm{NH}_{2}-\mathrm{dNTPS}$ are incorporated into DNA by purified mammalian DNA polymerases. In addition, the authors concluded that upon incorporation, the analog led to termination of chain growth. If this is occurring in intact cells, the incorporation of $3^{\prime}$ $\mathrm{NH}_{2}$-ddCTP into the growing DNA strand could account for the observed inhibition of DNA synthesis and chain elongation. As noted above, the absence of incorporated analog in cellular DNA in a previous study [7] may have been due to removal of incorporated analog by repair enzymes. Exonuclease activity associated with purified DNA polymerase $\alpha$ [21-23] and polymerase $\varepsilon$ [21] have been shown to be capable of excising incorporated araC residues in vitro. However, other studies using intact cells have proposed that araC residues in DNA are not removed at all and are elongated into high molecular weight DNA [20]. In addition, in vitro studies with $2^{\prime}, 2^{\prime}$ difluorodeoxycytidine ( $\mathrm{dFdC}$ ) [21] have shown that 3 -terminal residues are not excised by polymeraseassociated proofreading activity and that incorporated analog is utilized as a substrate for further nucleotide addition.

Excision of $3^{\prime}$ - $\mathrm{NH}_{2}$-ddCTP incorporated into nascent DNA by mammalian replicative DNA polymerases could lead to very low levels of drug incorporation. The concentration-dependent inhibition of DNA chain elongation observed with $3^{\prime}-\mathrm{NH}_{2}$-ddCyd exposure [Table $2 ;$ Ref. 7] would then be the result of the process of recognition, excision and continued elongation of $3^{\prime}-\mathrm{NH}_{2}$-ddCydterminated DNA fragments. The $3^{\prime}-5^{\prime}$ exonuclease associated with DNA polymerase $\delta$ is incapable of excising incorporated AZT or ddCyd residues, which, similarly to $3^{\prime}-\mathrm{NH}_{2}$-ddCTP, act to terminate chain growth in vitro [24]. The lack of excision by the polymerase-associated exonuclease activity may simply be due to the fact that AZTTP and ddCTP are not substrates for the enzyme and therefore cannot bind to the active site of the enzyme. If, as suggested by Chidgeavadze et al. [10], 3'- $\mathrm{NH}_{2-}$ ddCTP does serve as a substrate for the replicative enzymes, then polymerase-associated exonuclease activity, upon recognition of a misincorporated drug molecule, may remove it and continue synthesizing DNA. However, under conditions where repair capacity may be saturated (i.e. exposure to $20 \mu \mathrm{M}$ $3^{\prime}-\mathrm{NH}_{2}$-ddCyd), incorporated drug molecules may persist at the $3^{\prime}$-terminus. This may explain the differential rates of chain elongation at the replication fork with high and low concentrations of $3^{\prime}-\mathrm{NH}_{2}-$ ddCyd (Table 2).

If $3^{\prime}-\mathrm{NH}_{2}$-ddCyd is incorporated into nascent DNA fragments and not excised or elongated prior to initiation of an adjacent DNA fragment, the $3^{\prime}$ ends of these fragments would remain blocked. Therefore, another possible mechanistic difference that may exist between $3^{\prime}-\mathrm{NH}_{2}$-ddCyd and aphidicolin is the ligation of adjacent replicative intermediates. Aphidicolin has been shown to have no effect on the ligation of DNA fragments $[25,26]$, while araC at the 3 '-terminus of DNA fragments has been shown to slow but not block ligation in vitro [23]. The slowed elongation of Okazaki fragment-sized replicative intermediates upon chase in the absence of the drug (Figs. 4B and 5) and the decrease in available $3^{\prime}$-ends in the ssDNA replicative intermediates (Table 4) and the high molecular weight dsDNA (Table 3) suggest that analogterminated fragments do persist in cells exposed to $20 \mu \mathrm{M} \mathrm{3}^{\prime}-\mathrm{NH}_{2}$-ddCyd, and therefore an inhibition of the ligation by these $3^{\prime}-\mathrm{NH}_{2}$-ddCyd-terminated fragments may contribute to the inhibition of elongation of DNA intermediates in $3^{\prime}-\mathrm{NH}_{2}$-ddCydtreated cells.

The decrease in the enzyme-catalyzed incorporation of nucleotides into DNA isolated from cells 
treated with $20 \mu \mathrm{M} 3^{\prime}-\mathrm{NH}_{2}$-ddCyd (Tables 3 and 4) provides strong support for the hypothesis that $3^{\prime}$ $\mathrm{NH}_{2}$-ddCyd is incorporated into cellular DNA. DNA from cells exposed to aphidicolin or $2.5 \mu \mathrm{M} 3^{\prime}-\mathrm{NH}_{2}$ ddCyd, conditions which did not inhibit cell viability, did not show a decrease in either the Klenowcatalyzed polymerization of nucleotides on dsDNA, or the addition of ddATP to ssDNA pieces by terminal transferase. With regard to aphidicolin, this suggests that under these conditions the alteration of $3^{\prime}$-termini is not involved in its inhibitory effects on DNA synthesis. On the other hand, in the presence of a low concentration of $3^{\prime}-\mathrm{NH}_{2}$-ddCyd, previously blocked 3 '-ends may be overcome possibly through excision repair. This turnover of blocked 3 '-ends would slow the elongation of replication intermediates. Consistent with this hypothesis, in sampies exposed to $2.5 \mu \mathrm{M} 3^{\prime}-\mathrm{NH}_{2}$-ddCyd, Okazaki fragment-sized DNA was elongated to a lesser degree than that observed in samples treated with either concentration of aphidicolin (Fig. 5). However, the relatively rapid rate of elongation of Okazakisized fragments as compared with that observed with higher concentrations of $3^{\prime}-\mathrm{NH}_{2}$-ddCyd and the apparent absence of inactivated $3^{\prime}$-ends in ssDNA from cells exposed to $2.5 \mu \mathrm{M} 3^{\prime}-\mathrm{NH}_{2}$-ddCyd suggest that this turnover of $3^{\prime}$-termini is a relatively rapid process. If this "proofreading" occurs at the replication fork, this process is apparently saturable with time, since upon a 24 -hr exposure to $2.5 \mu \mathrm{M}$ $3^{\prime}-\mathrm{NH}_{2}$-ddCyd, cell viability is reduced by $50 \%$ [4]. It is also saturable with increasing concentrations of $3^{\prime}-\mathrm{NH}_{2}$-ddCyd as suggested from a similar loss of cell viability after exposure to $20 \mu \mathrm{M} 3^{\prime}-\mathrm{NH}_{2}$-ddCyd for $9.5 \mathrm{hr}$ (Table 1).

The similarity between the percent loss of cell viability (Table 1) and the decreased reactivity of $3^{\prime}$-ends in purified DNA (Tables 3 and 4) under the conditions analyzed suggests a possible relationship between the generation of non-reactive $3^{\prime}$-ends in DNA by cytotoxic agents and their induction of cell death. Although this is only a tenuous connection that requires further study, there is prior evidence of such a possible relationship with ara-C. Kufe $e t$ al. [20] found that DNA isolated from L1210 cells treated with ara-C was also a poor substrate for Klenow catalyzed nucleotide addition. Furthermore, this effect was concentration dependent in that DNA from cells exposed to high concentrations of ara-C, which decreased clonogenicity by $80 \%$, was a poor substrate, while DNA isolated from cells treated with a lower concentration of the drug, which only decreased viability by $20 \%$, did not demonstrate any altered reactivity. Internucleotide incorporation of ara-C could skew these results, but there may be a casual relationship between altered 3 '-termini and cell viability.

In summary, 3'- $\mathrm{NH}_{2}$-ddCyd exerted a concentration-dependent inhibition of DNA chain elongation at the replication fork in L1210 cells. Chidgeavadze et al. [10] have proposed the incorporation, in vitro, of $3^{\prime}$-amino-2', $3^{\prime}$-dideoxynucleoside triphosphates by purified mammalian DNA polymerase $\alpha$, resulting in chain termination. The present study suggests that incorporation of the analog into the growing strand of DNA by replicative
DNA polymerases may be the mechanism by which $3^{\prime}-\mathrm{NH}_{2}$-ddCyd inhibits DNA synthesis in tumor cells.

Acknowledgements - This investigation was supported by Grant $\mathrm{CH}-452$ from the American Cancer Society. This paper was submitted by M. S. W. in partial fulfilment of the degree of Doctor of Philosophy to the faculty of the Department of Pharmacology at the University of Michigan.

\section{REFERENCES}

1. Creasey WA, Papac RJ, Markiw ME, Calabresi $P$ and Welch AD, Biochemical and pharmacological studies with 1- $\beta$-D-arabinofuranosylcytosine in man. Biochem Pharmacol 15: 1417-1428, 1966.

2. Chabner BA, Johns DG, Coleman CN, Drake JC and Evans WH, Purification and properties of cytidine deaminase from normal and leukemic granulocytes. $J$ Clin Invest 53: 922-931, 1974.

3. Lin T-S and Mancini WR, Synthesis and antineoplastic activity of $3^{\prime}$-azido and $3^{\prime}$-amino analogues of pyrimidine deoxyribonucleosides. J Med Chem 26: 544-548, 1983.

4. Mancini WR and Lin T-S, Ribo- and deoxyribonucleoside effect on $3^{\prime}$-amino-2',3'-dideoxycytidineinduced cytotoxicity in cultured L1210 cells. Biochem Pharmacol 32: 2427-2432, 1983.

5. Mancini WR, The role of deoxycytidine-metabolizing enzymes in the cylotoxicity induced by $3^{\prime}$-amino- $2^{\prime}, 3^{\prime}$ dideoxycytidine and cytosine arabinoside. Cancer Chemother Rep 30: 139-144, 1992.

6. Kufe DW, Major PP, Egan EM and Beardsley GP, Correlation of cytotoxicity with incorporation of araC into DNA. J Biol Chem 255: 8997-9000, 1980.

7. Mancini WR, Williams MS and Lin T-S, Specific inhibition of DNA biosynthesis induced by $3^{\prime}$-amino$2^{\prime}, 3^{\prime}$-dideoxycytidine. Biochemistry 27: 8832-8839, 1988.

8. Chen MS, Woods KL and Prusoff WH, Molecular basis of the antineoplastic activity of 3 '-amino-3'deoxythymidine. Mol Pharmacol 25: 441-445, 1984.

9. Momparler RL, Biochemical pharmacology of cytosine arabinoside. Med Pediatr Oncol Suppl 1: 45-48, 1982.

10. Chidgeavadze ZG, Beabealashvilli RSh, Atrazhev AM, Kukhanova MK, Azhayev AV and Krayevsky AA, $2^{\prime}, 3^{\prime}$-Dideoxy-3' aminonucleoside 5'-triphosphates are the terminators of DNA synthesis catalyzed by DNA polymerases. Nucleic Acids Res 12: 1671-1686, 1984.

11. Huberman JA, New views of the biochemistry of eucaryotic DNA replication revealed by aphidicolin, an unusual inhibitor of DNA polymerase $\alpha$. Cell 23: $647-648,1981$.

12. Oguro M, Suzuki-Hori C, Nagano $H$, Mano $Y$ and Ikegami $S$, The mode of inhibitory action by aphidicolin on eukaryotic DNA polymerase $\alpha$. Eur J Biochem 97 : 603-607, 1979.

13. Lonn $U$ and Lonn $S$, Aphidicolin inhibits the synthesis and joining of short DNA fragments but not the union of 10-kilobase DNA replicalion intermediates. Proc Natl Acad Sci USA 80: 3996-3999, 1983.

14. Kantner PM and Schwartz HS, A hydroxylapatite batch assay for quantitation of cellular DNA damage. Anal Biochem 97: 77-94, 1979.

15. Kapp LN, Brown SL and Klevecz RR, Detecting small quantities of DNA on CsC gradients. Biochim Biophys Acta 361: 140-143, 1974.

16. Kaufmann SH, Desnoyers S, Ottaviano Y, Davidson NE and Poirier GG, Specific proteolytic cleavage of poly (ADP-ribose) polymerase: An early marker of chemotherapy-induced apoptosis. Cancer Res 53: 39763985, 1993.

17. Beabealashvilli RS, Scamrov AV, Kutateladze TV, 
Mazo AM, Krayevsky AA and Kukhanova MK, Nucleoside 5'-triphosphates modified at sugar residues as substrates for calf thymus terminal deoxynucleotidyl transferase and for AMV reverse transcriptase. Biochim Biophys Acta 868: 136-144, 1986.

18. Major PP, Egan EM, Herrick DJ and Kufe DW, Effect of ara-C incorporation on deoxyribonucleic acid synthesis in cells. Biochem Pharmacol 31: 2937-2940, 1982.

19. Holmes AM, Studies on the inhibition of highly purified calf thymus $8 \mathrm{~S}$ and $7.3 \mathrm{~S}$ DNA polymerase $\alpha$ by aphidicolin. Nucleic Acids Res 9: 161-168, 1981.

20. Kufe DW, Munroe D, Herrick D, Egan E and Spriggs $D$, Effects of $1-\beta$-D-arabinofuranosylcytosine incorporation on eukaryotic DNA template function. Mol Pharmacol 26: 128-134, 1984.

21. Iluang $P$, Chubb $S$, Hertel LW, Grindey $G B$ and Plunkett W, Action of 2',2'-difluorodeoxycytidine on DNA synthesis. Cancer Res 51: 6110-6117, 1991.
22. Townsend AJ and Cheng Y-C, Sequence-specific effects of ara-5-aza-CTP and ara-CTP on DNA synthesis by purified human DNA polymerases in vitro: Visualization of chain elongation on a defined template. $\mathrm{Mol}$ Pharmacol 32: 330-339, 1987.

23. Mikita $T$ and Beardsley GP, Functional consequences of the arabinosylcytosine structural lesion in DNA. Biochemistry 27: 4698-4705, 1988.

24. Vasquez-Padua MA, Starnes MC and Cheng Y-C, Incorporation of $3^{\prime}$-azido-3'-deoxythymidine into cellular DNA and its removal in a human leukemic cell line. Cancer Commun 2: 55-62, 1990.

25. Wist $\mathrm{E}$ and Prydz $\mathrm{H}$, The effect of aphidicolin on DNA synthesis in isolated HeLa cell nuclei. Nucleic Acids Res 6: 1583-1590, 1979.

26. Yagura T, Kozu T and Seno T, Arrest of chain growth of replicon-sized intermcdiates by aphidicolin during rat fibroblast cell chromosome replication. Eur $J$ Biochem 123: 15-21, 1982. 